\title{
ADAPTATION OF MANAGEMENT ORGANIZATION STRUCTURES TO CHANGES IN ACTIVITIES OF A PRINCIPAL CONTRACTOR IN THE PROCESS OF CONSTRUCTION ORGANIZATION BASED ON ENGINEERING METHODS
}

\section{Tugai O. A.}

\section{INTRODUCTION}

Management organization engineering is defined as activities in connection with the design, implementation, and development of management systems, performed in order to enhance the efficiency of construction investment projects and construction entrepreneurial business in whole. The management organization engineering is oriented to the design and implementation of management systems, including management systems required for functioning and development of enterprises, and is mandatory part of construction investment activities because of the necessity to develop, additionally to the necessity to maintain the enterprise capital assets, an efficient management system in connection with the specified investment project. In reorganization of enterprises, the management organization engineering may be provided independent of construction investment projects. The management organization engineering methods are efficiently used for such purposes:

1. To renew the content, facilities, and objectives of business processes.

2. To exercise anti-recessionary management, specifically in the case of bankruptcy of the enterprise.

3. To enhance the efficiency of the enterprise activities by using restructuring, reconstruction, and reorganization processes.

4. To act, in accordance with decisions of antimonopoly agencies, in the case of violation of the appropriate law by the enterprise.

In general, the management organization engineering activities are classified as follows:

1. The management organization engineering activities for achieving the enterprise strategic objectives.

These activities are oriented to the making and implementation of decisions concerning the operation and development of the enterprise and the impact of the enterprise on the environment. These activities are characteristic for business management systems. 
2. The management organization engineering activities for establishing the enterprise management structure.

These activities are oriented to the making and implementation of decisions concerning the hierarchic structure of the enterprise, interaction between the enterprise operational units, and allocation of responsibility of the enterprise operational units.

3. The management organization engineering activities for maintaining management processes.

These activities are oriented to the making and implementation of decisions concerning exchange of information and technologies between the enterprise operational units.

The management organization engineering shall be actualized in an auxiliary project ${ }^{1}$, as part of the general construction investment project, or in an individual project when the management organization engineering relates to the optimization of operation, anti-recessionary management, or enforced reorganization of the existing enterprise ${ }^{2}$. Because of this, all known methods and approaches used for project management can also be used for the management organization engineering.

\section{Management organization engineering activities \\ for developing optimal management organization structure models for construction enterprises as principal contractors in implementing construction investment projects}

The management organization structure models shown in Figure 1 were developed in order to implement management organization engineering methods for modernization of management systems of construction enterprises. According to these models, the management organization process consists of four stages discussed below.

1. The stage of diagnostics for determining the management organization state at the enterprise and for justifying the necessity to change the management organization structure model for the enterprise.

2. The stage of developing the ideal management organization structure model.

3. The stage of readjustment of business processes at the enterprise in order to adapt the processes to the new management organization structure, that is, the stage of designing the management organization structure model for the state of the enterprise to be in the nearest future.

1 Bovykin V.I., New management (management of enterprises in accordance with standards: theory and practice of effective management); Moscow, Ekonomika, 1997, 302 pp.

2 Bocharov V.Y., Investment management: management of investment activities; St. Petersburg, Publishing office of the Economy and Finance University, 1999, 284 pp. 
4. The stage of implementing the new management organization structure model.

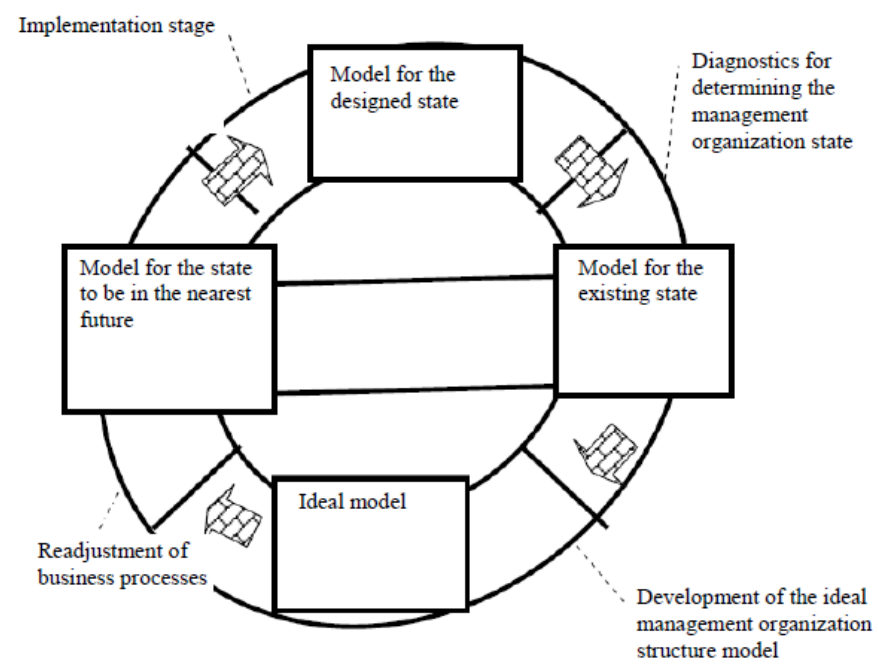

Fig. 1. Four-stage management organization process and management organization structure models

The objectives at the first stage of the management organization engineering process are the following:

1. To perform the initial diagnostics change the management of the enter4prise state in order to detect problems that caused the necessity to organization structure model.

2. To perform the detailed diagnostics of the enterprise state and collect information required for developing the new management organization structure.

3. To analyze the enterprise state in order to determine strategic objectives of the enterprise activities, including the following:

3.1. To determine the strategic areas and centers of the enterprise activities.

3.2. To determine the strategic situation of the enterprise, analyze the environment, and determine the effect of the environment on the enterprise.

3.3. To determine the key factors for the successful operation of the enterprise and determine the enterprise activity objectives.

4. To analyze the state of management and organization ate the enterprise, including the following: 
4.1. To analyze the management organization structure of the enterprise.

4.2. To analyze the management processes and the allocation of management functions and tasks at the enterprise.

4.3. To analyze the efficiency of the management system elements.

5. To analyze the financial and economic activities of the enterprise with consideration for the basic efficiency factors.

6. To analyze the enterprise data management system, including the following system elements:

6.1. Flows of documents and data at the enterprise.

6.2. Data structure.

6.3. The data communication and processing equipment such as local computer network equipment, servers, and workstations

6.4. Office equipment and its use.

7. To analyze the enterprise personnel management system, including the following:

7.1. To analyze the enterprise personnel capabilities.

7.2. To analyze the social and psychological state of the enterprise personnel.

7.3. To analyze the informal relations between the personnel members and code of behavior accepted at the enterprise.

8. To analyze the production activities and technologies of the enterprise, including the following:

8.1. To analyze the existing production processes.

8.2. To develop the management organization structure model for the existing state of the enterprise.

8.3. To perform the end-to-end analysis for determining development problems in relation to the systems, organizational structure, production processes, and other elements of the enterprise.

The objectives at the second stage of the management organization engineering process, that is, the stage of developing the ideal management organization structure model for the enterprise, are the following ${ }^{3}$ :

1. To develop and analyze the possible methods for solving the existing problems in connection with the management organization structure of the enterprise.

2. To simulate the effect of the environment on the management organization structure.

3. To develop alternative management organization structure models.

\footnotetext{
${ }^{3}$ Dmytruk I.A., Torkatiuk V.I., Mariukhin V.M., Characteristic features and basic areas of activities for enhancing efficiency of project decisions; Materials of the 23rd scientific and technical conference of the Kharkiv State Academy of Municipal Economy, Kharkiv, 2007, pp. 105-117.
} 
4. To analyze and estimate the developed management organization structure models in accordance with the criteria specified by the expert agency.

5. To determine the optimal management organization structure model.

The objectives at the third stage of the management organization engineering process, that is, the stage of readjustment of business processes at the enterprise, are the following:

1. To determine the strategic objectives of the enterprise activities.

2. To develop the management organization structure of the enterprise.

3. To develop the business and management processes of the enterprise.

4. To develop the enterprise data management system, including data flows, data structures, hardware, application software, and office equipment.

5. To develop the production processes and technologies of the enterprise.

6. To develop personnel management system of the enterprise and code of behavior at the enterprise.

7. To perform scheduling and resource planning operations.

8. To determine the economic efficiency possible in the result of implementation of the management organization structure model.

The objectives at the fourth stage of the management organization engineering process, that is, the stage of implementing the new management organization structure model for the enterprise, are the following:

1. To develop the documentation required for implementing the new management organization structure model.

2. To select personnel for implementing the new management organization structure model.

3. To respond to the opposition of the part of the enterprise personnel to organizational reassignments.

4. To control changes and compromises.

5. To control plans and determine corrective and preventive actions.

6 . To develop documentation and the management organization structure model for the designed state of the enterprise.

7. To analyze the results achieved.

8. To use the implemented management organization structure model.

9. To estimate the advantages and disadvantages of the accepted management organization structure model according to the results of the enterprise activities.

The stage of diagnostics for determining the management organization state at the enterprise includes management organization engineering activities corresponding to an individual project of the reorganization of the existing enterprise. This stage is also known as a reverse engineering stage, which objective is to develop the management organization project for the 
existing enterprise. The reverse engineering stage is followed by a direct engineering stage, which objective is to develop the management organization structure model to be implemented.

For new enterprises, the stage of diagnostics is associated with the analysis of the environment required for implementation of the investment project, as well as with the analysis of the target objectives and efficiency factors characterizing the enterprise management system.

Some objectives, which are characteristic for the management organization engineering, can be achieved by using other engineering methods. Specifically, the analysis of the financial and economic state of the enterprise is part of engineering activities for financial and economic systems, analysis of the personnel management system of the enterprise is part of engineering activities for personnel management systems, and analysis of the data acquisition and processing system of the enterprise is part of engineering activities for information systems.

The important characteristic of the management organization engineering is the unity of methods used in the reverse engineering and in the direct engineering for developing the ideal and specific management organization structure models, that is, the same methods are used for analyzing the existing business processes and for developing perspective business processes.

The management organization engineering process is illustrated by the diagram shown in Figure 1. The management organization engineering models shown on the diagram are designed for enhancing the efficiency of the enterprise management system.

The management organization engineering process is a process of transition from the stage of the project development to the stage of the project implementation, and coherent transition from the model for the existing state of the enterprise to the model for the state of the enterprise to be in the nearest future ant then to the model for the designed state of the enterprise.. Due to the management organization engineering process, the efficiency of the enterprise activities enhances. The main objectives of the management organization engineering process are to analyze the enterprise activities and use the analysis results in making decisions in connection with the enterprise management organization. So, the readjustment of the enterprise management organization structure in the case of the existing enterprise and the implementation of the management organization structure in the case of a new enterprise shall be performed in accordance with the management organization engineering process. For developing the optimal variant of the management organization structure, it is necessary to know the enterprise life cycle. The life cycle characteristic of the construction enterprise is shown in Figure 2. 


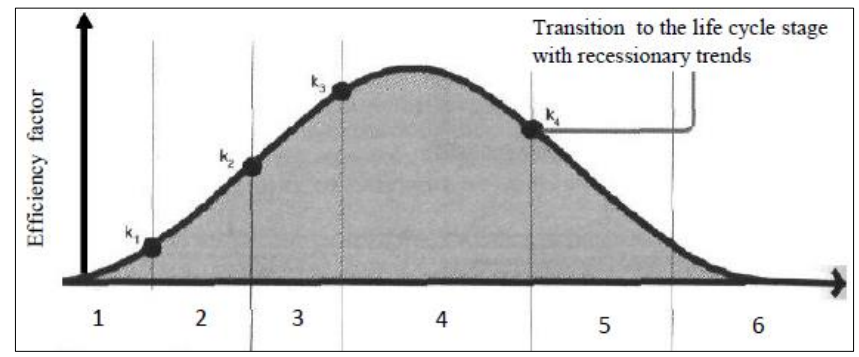

Fig. 2. Life cycle characteristic of the construction enterprise

1. Establishment of the enterprise

2. Accelerated development

3. Decelerated development

4. Normal activities

5. Recession

6. Decay

Note

The efficiency factor value shall be specified by an expert agency.

At the stage of establishment, the enterprise is characterized by enhanced expenses, and the revenues obtained from the enterprise operation do not cover the expenses, that is, the enterprise operation is unprofitable. At the beginning, the enterprise does not carry on productive activities and suffer losses due to construction, purchase, registration, or reconstruction of production buildings and rooms, supply of equipment and materials, and engaging of employees. Later, the enterprise starts productive activities but without profit. So, the enterprise activities at this stage are profitless. This stage can last for a period from several months (for enterprises that are not registered as a legal entity, or for trade and procurement enterprises) to $3 \ldots$ 4 years (for industrial enterprises).

During the life cycle, the enterprise, in the process of its development, passes over the critical point $k_{1}$ corresponding to the start of lossless activities of the enterprise, and proceeds to the stage where the cost of resources used for the enterprise operation and the income of the enterprise are equal. At this stage, the strategic potential of the enterprise is formed, and the competitive advantages of the enterprise arise.

The stage of accelerated development and the stage of decelerated development of the enterprise are characterized by sufficiently intensive activities. At the stage of accelerated development, the production capacity 
of the enterprise and, as a result, the competitive advantages, volume of production, and income of the enterprise arise.

At the stage of decelerated development, the production capacity of the enterprise decreases, and the operating efficiency of the enterprise is near maximum.

At the stage of normal activities, the operating efficiency, volume of sales of products, and income of the enterprise are maximal. The state of the enterprise is stable, and the enterprise does not extend. At this stage, the enterprise managers shall determine the conditions for extending this stage so far as is possible. At the end of this stage, the enterprise proceeds gradually to the recession stage, but maintains its market power.

The recession stage is characterized by sharp decrease of income and loss of business activity of the enterprise. This stage occurs, primarily, due to the activities of competitive enterprises and decrease of the production capacity of the enterprise. At this stage, all the finance indicators of the enterprise activities decline and the enterprise proceeds to the last life cycle stage, that is, the stage of decay.

At this stage, the enterprise suffers losses from its activities and can become bankrupt.

Ideal for the enterprise is the life cycle with the extended stage of normal activities. For construction enterprises, provided that the enterprise management is efficient in accordance with European standards, the multiperiod life cycle characteristic has been proposed (see Figure 3).

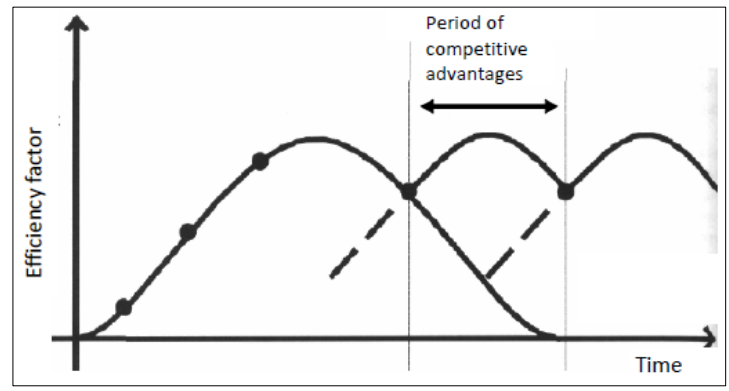

\section{Fig. 3. Multiperiod life cycle characteristic of the enterprise}

Crises are known as specific events in the enterprise life cycle. In accordance with the modern theory of enterprise development, the crisis state of the enterprise is illustrated in Figure 4. In this state, the production activity indicators of the enterprise become to be not complying with each other, and the relation between efficiency factors in performing the specified functions and processes at the enterprise sharply changes. 


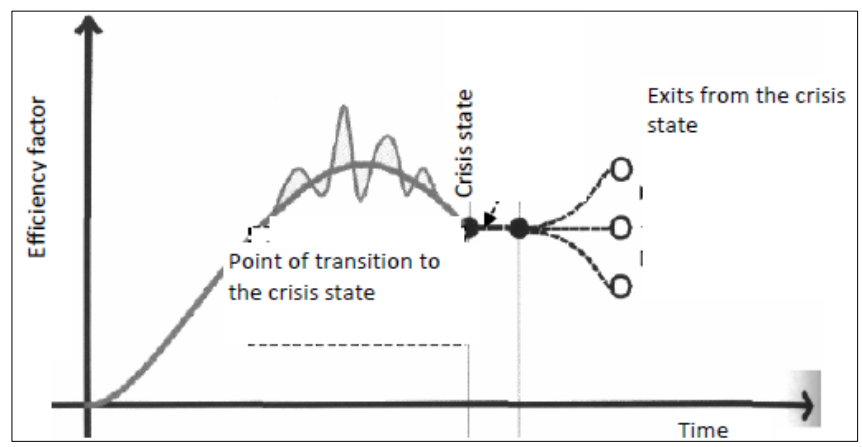

Fig. 4. Crisis state of the enterprise

In the crisis state, the production activity indicators of the enterprise are changing in a wide range, and the enterprise activities become unstable ${ }^{4}$. The instability causes loss of the financial reliability of the enterprise and, as a result, the nonequilibrium state which is characterized by the branching of the stable development possibilities for the enterprise. Depending on the enterprise management and other factors, the enterprise can choose one of the stable possibilities. In this case, the enterprise production capacity can increase or can decrease, in accordance with a steady trend, up to the bankruptcy of the enterprise.

So, the mandatory condition for efficient management organization engineering is the analysis of the enterprise characteristic features, enterprise life cycle, position of the enterprise at the market, and possible crisis events in the enterprise activities.

\section{Management organization structure models, based}

\section{on engineering methods, for construction enterprises as contractors in performing construction projects}

The management organization in the design area should be considered as organizational activity in developing management organization projects in accordance with new trends in the construction practice.

The primary document for developing the preliminary management organization project is the approved project specifications. The project specifications shall include the project justification, project objectives, requirements to the management organization structure, requirements to the

${ }^{4}$ Pokolenko V.O. and others, New methods of forming an investment portfolio in construction by optimizing the tax structure; Methods of increasing construction efficiency in market conditions, Collection of scientific papers, Kyiv, Kyiv National University of Civil Engineering and Architecture, 2006, Issue 15, pp. 3-10. 
management system, and the results of technical-economic analysis. The list of documents required for preparing the project specifications is presented in Table 1.

The preliminary management organization project shall include the results of development of the enterprise management system, description of the enterprise production structure, explanatory note to the project, and preliminary calculations of the expected economic effect.

Table 1

List of documents required for the project specifications

\begin{tabular}{|l|l|}
\hline \multicolumn{1}{|c|}{ Document } & \multicolumn{1}{c|}{ Content developer } \\
\hline $\begin{array}{l}\text { 1. Order on performing preparatory works for } \\
\text { developing the management organization project }\end{array}$ & $\begin{array}{l}\text { Manager of the construction engineering } \\
\text { company as the customer and performer } \\
\text { of the management organization project }\end{array}$ \\
\hline $\begin{array}{l}\text { 2. Methods of analyzing the state and production } \\
\text { activities of the existing enterprise }\end{array}$ & $\begin{array}{l}\text { Construction engineering company } \\
\text { together with engaged experts }\end{array}$ \\
\hline 3. Plan of the analysis & Construction engineering company \\
\hline 4. Report on the analysis results & $\begin{array}{l}\text { Construction engineering company } \\
\text { together with engaged experts }\end{array}$ \\
\hline 5. Project specifications & Construction engineering company \\
\hline
\end{tabular}

After the expert examination and approval of the preliminary management organization project, the detailed management organization project shall be developed. The objective of the detailed project is to develop the working documentation required for implementing and using the management organization structure at the enterprise. The list of documents required for the detailed management organization project is presented in Table 2.

After approval of the detailed management organization project, the project shall be implemented. At this stage, it is necessary to determine the sources of financing for the project, technical facilities, information support, and other elements of the management system, and to provide social and psychological support for the management personnel, which consists in informing the personnel about the objectives of management activities, code of behavior at the enterprise, and efficiency factors of the project to be implemented and solving social problems of the personnel.

Professional training of the management personnel is intended for the personnel development and familiarization of the personnel with new management technologies, new technical facilities, management systems, information support, and application software. Implementation of some facilities and systems may be accomplished in the process of the project 
development. It is recommended to provide a temporary promotion system for the specialists implementing such facilities and systems.

After the project implementation, the economic effect in connection with the project should be determined.

\section{List of documents required for the detailed management organization project}

\begin{tabular}{|l|c|c|}
\hline \multirow{2}{*}{ Document } & \multicolumn{2}{c|}{ To be used in: } \\
\cline { 2 - 3 } & $\begin{array}{c}\text { the management } \\
\text { system }\end{array}$ & $\begin{array}{c}\text { the subsystems of } \\
\text { the management } \\
\text { system }\end{array}$ \\
\hline $\begin{array}{l}\text { 1. List of managers and functions of the } \\
\text { managers responsible for the detailed } \\
\text { management organization project }\end{array}$ & $\times$ & $\times$ \\
\hline 2. Description of the manager functions & $\times$ & $\times$ \\
\hline $\begin{array}{l}\text { 3. Regulations for the enterprise management } \\
\text { personnel }\end{array}$ & $\times$ & $\times$ \\
\hline 4. Regulations for the manager responsibilities & & $\times$ \\
\hline $\begin{array}{l}\text { 5. Diagram of relations between the departments } \\
\text { of the management office of the enterprise }\end{array}$ & & $\times$ \\
\hline $\begin{array}{l}\text { 6. Description of the diagram of relations } \\
\text { between the departments of the management } \\
\text { office of the enterprise }\end{array}$ & $\times$ & $\times$ \\
\hline $\begin{array}{l}\text { 7. Duty regulations for the management } \\
\text { personnel }\end{array}$ & $\times$ & $\times$ \\
\hline 8. Table of the authorized management personnel & $\times$ & $\times$ \\
\hline $\begin{array}{l}\text { 9. Diagram of document workflow within the } \\
\text { enterprise management system }\end{array}$ & $\times$ & $\times$ \\
\hline $\begin{array}{l}\text { 10. Description of the diagram of document } \\
\text { workflow }\end{array}$ & $\times$ & $\times$ \\
\hline $\begin{array}{l}\text { 11. Engineering data of the management } \\
\text { facilities }\end{array}$ & $\times$ & $\times$ \\
\hline $\begin{array}{l}\text { 12. Analysis of expected economic effect due to } \\
\text { the project implementation }\end{array}$ & $\times$ & $\times$ \\
\hline $\begin{array}{l}\text { 13. Plan of measures for the project } \\
\text { implementation }\end{array}$ & $\times$ & $\times$ \\
\hline
\end{tabular}

The list of documents required for implementing the management organization project is presented in Table 3.

The methods for developing am implementing the management organization project depend on the conditions for management organization at the enterprise. 


\section{List of documents required for implementing \\ the management organization project}

\begin{tabular}{|l|c|}
\hline \multicolumn{1}{|c|}{ Document } & Content developer \\
\hline $\begin{array}{l}\text { 1. Financial plan for implementing the management } \\
\text { organization project }\end{array}$ & Customer \\
\hline $\begin{array}{l}\text { 2. Document on the material and technical resources required } \\
\text { for implementing the management organization project }\end{array}$ & Customer \\
\hline $\begin{array}{l}\text { 3. Document on the information support } \\
\text { of the management system }\end{array}$ & $\begin{array}{l}\text { Specialized agencies at the } \\
\text { expense of the customer }\end{array}$ \\
\hline $\begin{array}{l}\text { 4. Document on the social and psychological support } \\
\text { of the management personnel }\end{array}$ & $\begin{array}{l}\text { Customer } \\
\text { Designer }\end{array}$ \\
\hline $\begin{array}{l}\text { 5. Document on the professional training of the management } \\
\text { personnel }\end{array}$ & Customer \\
\hline $\begin{array}{l}\text { 6. Regulations on the promotion system for the specialists } \\
\text { implementing the project }\end{array}$ & Customer \\
\hline $\begin{array}{l}\text { 7. Calculations for determining the actual economic effect } \\
\text { due to the project implementation }\end{array}$ & Customer with designer \\
\hline 8. Report on the commissioning the project & $\begin{array}{l}\text { Customer } \\
\text { Designer }\end{array}$ \\
\hline
\end{tabular}

The results of research activities and propositions of the author of this paper, concerning the elements of the management systems and management organization structures designed for building enterprises as subjects of research, were verified in the process of practical activities of the construction engineering company «Construction and ecology». When developing the management organization project, characteristic features of construction enterprises, mutual relations of the construction enterprises with investors, and methods for estimating variants of the management organization structure were considered ${ }^{5}$.

In accordance with the discussed methods for developing management organization projects, the special procedure for developing management organization structures for construction enterprises has been proposed. This procedure is illustrated in Figure 5.

For the construction engineering company «Construction and ecology», several alternative variants of the management organization structure were proposed. These variants were compared in accordance with the technique discussed below.

${ }^{5}$ Pokolenko V.O. and others, New conceptual and analytical facilities for justification, preparation, and implementation of investment projects in construction; Monography under the editorship of Pokolenko V.O., Kyiv, Publishing office of the European University, 2008, 208 pp. 
The accepted variant of the management organization structure for the construction engineering company «Construction and ecology» is illustrated in Figure 6. The proposed management organization structure is designed as a multipurpose structure in which, in accordance with the theory of hierarchical systems, all the elements can take decisions and have various, even conflicting, objectives. Such contradictions are caused by the element specialization and are required for effective management of an enterprise. In a system with the multipurpose structure, the higher level elements enable the purposeful activities of the lower level elements but do not control the lower elements completely ${ }^{6}$.

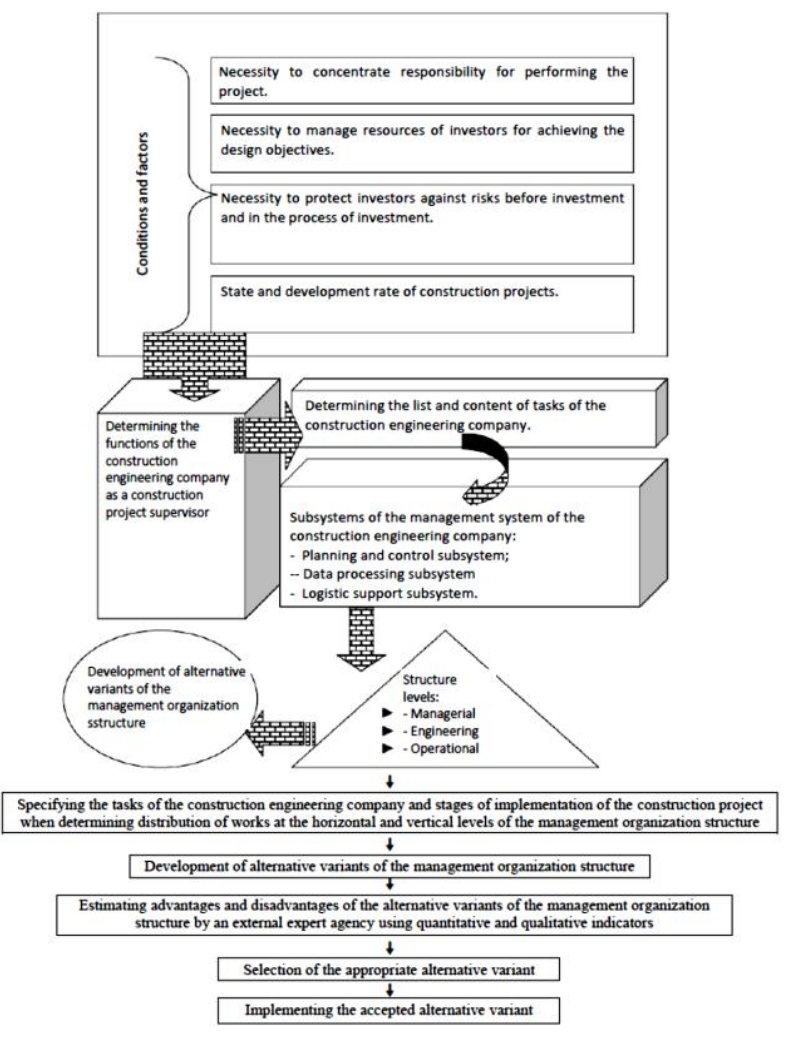

\section{Fig. 5. Procedure for developing the management organization structure of the construction engineering company}

${ }^{6}$ Tugai O.A., Lagutin G.V., New subjects of construction organization: methods, information base, and implementation practice; Monography, Publishing office of the European University, 2006, $180 \mathrm{pp}$. 


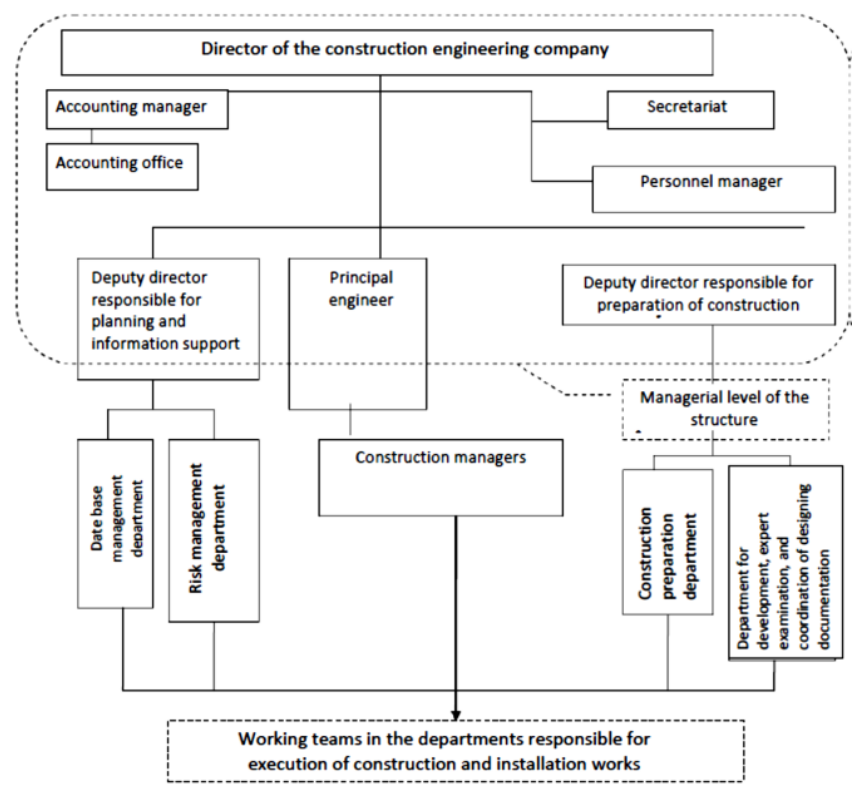

Fig. 6. Variant of the management organization structure of the construction engineering company
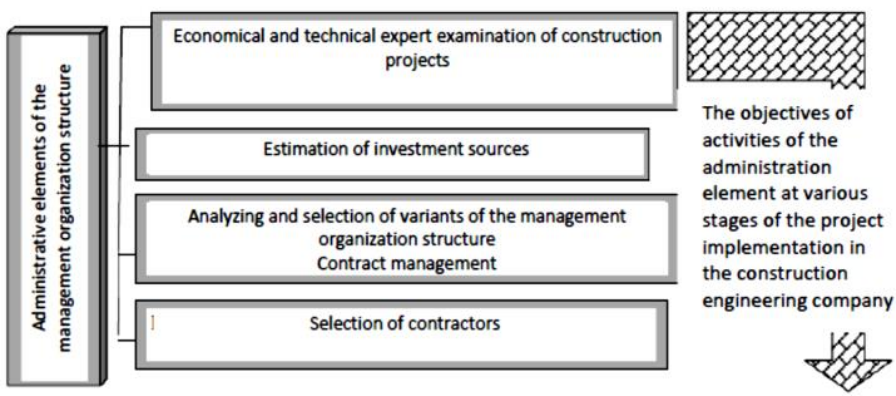

1. To analyze investment propositions, project objectives, and designing documentation 2. To analyze the proposed sources of financial support required for preparing and performing construction and installation works

3. To make decisions in relation to investors and the construction engineering company as a leading company in planning,. preparing, and performing construction and installation works

Fig. 7. Administrative elements of the management organization structure of the construction engineering company 
The lower level elements are free in taking decisions. This freedom is characteristic for any multilevel hierarchic system, and in the proposed management organization structure, management is provided by coordination of decisions accepted at the upper level with decisions accepted by the corresponding analytical and expert institutions.

The management organization structure (see Figure 6) is characterized by traditional advantages of function-branching structures, distribution of works, and hierarchic subordination of the structure elements ${ }^{7}$.

The managerial level of the management organization structure is represented by the manager of the enterprise and his deputies, which coordinate the enterprise activities and relations of the enterprise with investors, project performers, and other participants of the construction project.

The medium level of the management organization structure is represented by the experts of the following departments ${ }^{8}$ :

1. The department for risk management

2. The department for development, expert examination, and coordination of designing documentation

3. The planning and analysis department

4. The department for preparation of construction and installation works

5. The department for organization of construction and installation works

The lower level of the management organization structure is represented by the experts of the project management department.

The department for risk management is designed for performing special functions, such as estimating investment propositions, strategic objectives of the project, designing documentation, and sources of financing, and for making decisions concerning the activities of the construction engineering company as a principal contractor in performing construction and installation works.

The department for development, expert examination, and coordination of designing documentation is represented by the manager of the

${ }^{7}$ Tugai O.A., Multi-stage engineering model for organization of interaction between the principal contractor and the customer; Tugai O.A., Construction engineering, Kyiv, Kyiv National University of Civil Engineering and Architecture, 2008, No. 21, pp. 85-97.

${ }^{8}$ Tugai O.A., The functional-technical factor of efficiency of projects and structures of construction engineering companies as a new parameter in simulation of construction; Tugai O.A., Applied geometry and engineering graphics, Interdepartmental collection of scientific papers, Kyiv, Kyiv National University of Civil Engineering and Architecture, 2008, Issue 79, pp. 140-150. 
department, principal project architect, principal project engineer, architects, managers for contract administration, economists, operators of the computeraided design system, and operators of the automated cost calculation system ${ }^{9}$.

The planning and analysis department is designed for performing the following tasks:

1. Developing logistic schedules

2. Financial planning and selection of source of financing

3. Scheduling the project works and control resources required for performing the project

The department for preparation of construction and installation works is designed for performing the following tasks:

1. Selection of contractors for performing construction and installation works

2. Preparation of construction and installation works

3. Logistical organization

4. Rent of construction equipment

In order to prevent the inadaptability of enterprises tor rapid changes, the department for preparation of construction and installation works shall perform functions of a project supervisor.

The personnel of this department are represented by managers and constructing engineers, such as the following:

1. The manager and constructing engineers responsible for engineering works

2. The manger and constructing engineers responsible for operation of construction equipment

3. The manager and constructing engineers responsible for underground works

6. The manager and constructing engineers responsible for finishing works

7. The manager and constructing engineers responsible for special works

With consideration for special functions to be performed by the managers and constructing engineers of this department, the department should be decentralized. In this case, the medium level managers can make important decisions with consideration for motivating factors for these

${ }^{9}$ Tugai O.A., Method of functional-technical reorganization of construction; Tugai O.A., Town development and territorial planning, Collection of scientific papers, Kyiv, Kyiv National University of Civil Engineering and Architecture, 2006, Issue 30, pp. 398-419. 
decisions, and for this purpose, the management organization structure projects should be performed with consideration for the possibility for managers to propose, at special meetings, means for improving the management organization structure. The meetings shall be held under control of top managers, but when the decision is approved, it is mandatory for all the meeting participants.

The approved variant of the management organization structure allows for planning construction works, legal support of construction projects, effective relations with central and local authorities, and management of constriction objects in accordance with the specified requirements and coordinated interests and actions of all the project participants.

The approved variant of the management organization structure for the construction engineering company «Construction and ecology» complies with the objectives of the company as the administrator of investments and regulator of business processes.

The administrative elements of the management organization structure of the construction engineering company are shown in Figure 8.

The variant of the management organization structure for the UkrainianTurkish company «Ashgel Construction» is illustrated in Figure 9.

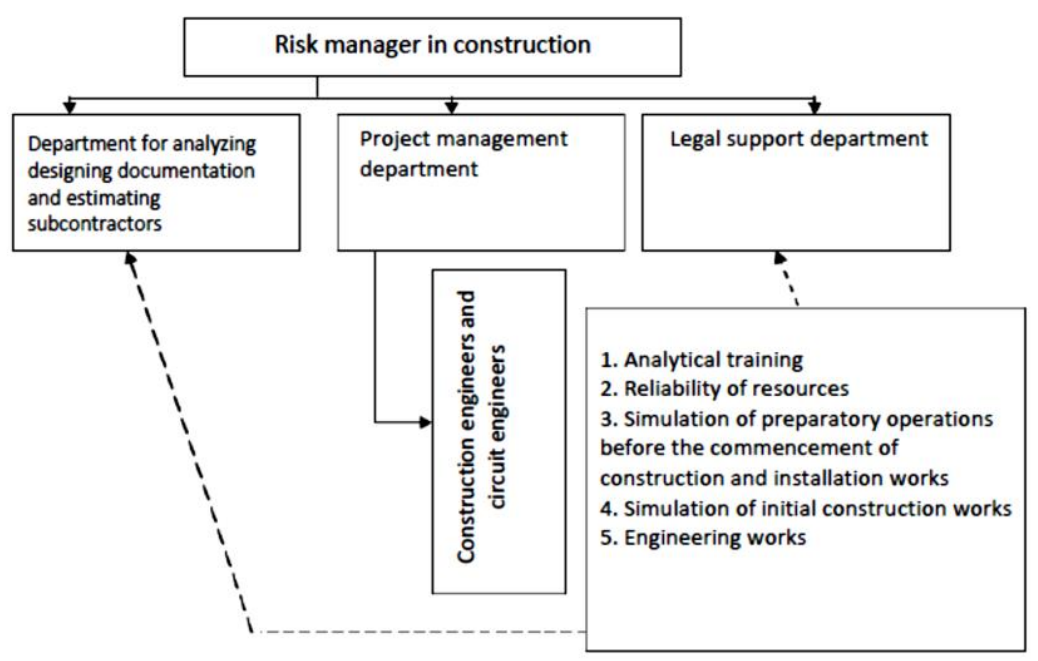

Fig. 8. Administrative elements of the management organization structure of the construction engineering company 


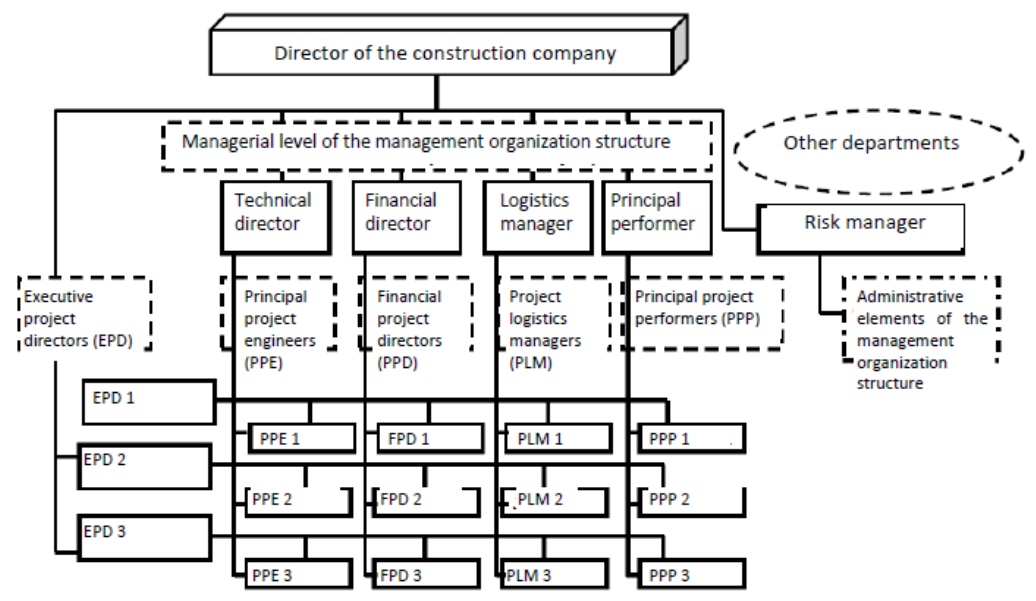

Fig. 9. Variant of the management organization structure for the Ukrainian-Turkish company «Ashgel Construction»

In this paper, the method for estimating the efficiency of variants of the management organization structure for construction engineering companies is proposed by using a special efficiency factor $U^{\prime s t r}$ depending on the structure characteristic features listed in Table 4.

The efficiency factor $U^{\prime \prime s t r}$ shall be determined by equation (1).

$$
\tilde{U}^{\prime s t r}=\left[1 /\left(m \cdot \mathrm{n}_{m} R g_{m}\right] \cdot \mathrm{n}_{m} \hat{S}_{m} ; R g_{m} \geq 1,\right.
$$

where:

$$
\hat{S}_{m}=\left(1 / \mathrm{n}_{z} R g_{z}\right) \cdot \mathrm{n}_{z} R g_{z} \hat{S}_{m z} ; z=1 \mathrm{n} N z ; R g_{z} \geq 1,
$$

$U^{\prime s t r}$ is the summary efficiency factor value presented as a rational number;

$m$ is the index equal to the sequential number of the corresponding characteristic feature in the list in Table 4;

$N$ is the total number of characteristic features in the list in Table 4;

$z$ is the index equal to the sequential number of the corresponding expert in the list of experts;

$\hat{S}_{m z}$ is the efficiency factor proposed by the $z$ th expert, according to the $m t h$ characteristic feature, for the variant of the management structure;

$\hat{S}_{m}$ is the efficiency factor accepted by all the experts; 
$R g_{z}$ is the indicator of importance of the expert efficiency factor for the $m t h$ characteristic feature relative to the efficiency indicator accepted by all the other experts;

$\mathrm{Rg}_{\mathrm{m}}$ is the indicator of the priority of the mth characteristic feature relative to the other characteristic features.

Table 4

\section{List of characteristic features in estimating the efficiency of variants of the management organization structure for construction engineering companies}

\begin{tabular}{|l|c|}
\hline \multicolumn{1}{|c|}{ Characteristic feature } & $\begin{array}{c}\text { Relative priority } \\
\text { indicator (Rg } \mathbf{m} \text { ) }\end{array}$ \\
\hline $\begin{array}{l}\text { 1. Adaptability } \\
\text { The capability of the management organization structure to allow for } \\
\text { performance of specified function of the enterprise within a range of } \\
\text { various conditions. The wider is the range, the more adaptable is the } \\
\text { management organization structure. }\end{array}$ & 1.11 \\
\hline $\begin{array}{l}\text { 2. Adjustability } \\
\text { The capability of the enterprise administration to make decisions and } \\
\text { enter into new relations, in response to new objectives of the enterprise } \\
\text { activities, without changes in the enterprise hierarchical structure. }\end{array}$ & 1.045 \\
\hline $\begin{array}{l}\text { 3. Operational efficiency in taking managerial decisions } \\
\text { The capability of the enterprise administration to promptly determine } \\
\text { problems in the enterprise management and solve the problems detected } \\
\text { as needed for achieving the specified objectives on retention of the } \\
\text { existing production environment at the enterprise. }\end{array}$ & 1.072 \\
\hline $\begin{array}{l}\text { 4. Minimization of conflicts between the elements of the management } \\
\text { organization structure. }\end{array}$ & 1.0 \\
\hline $\begin{array}{l}\text { 5. The capability of the management organization structure to provide } \\
\text { adequate working conditions for making decisions and carry out actions } \\
\text { for the personnel involved in the management organization. }\end{array}$ & 1.0 \\
\hline $\begin{array}{l}\text { 6. Promotion of team spirit at all the levels an in all the departments of } \\
\text { the enterprise. }\end{array}$ & 1.0 \\
\hline $\begin{array}{l}\text { 7. Information capacity of the enterprise communication system, the } \\
\text { number and quality of feedback links in information interchange } \\
\text { between the managers and employees of the enterprise }\end{array}$ & 1.09 \\
\hline $\begin{array}{l}\text { t8. Time of response as an interval between the start a management } \\
\text { action and the response to the action }\end{array}$ & \\
\hline
\end{tabular}

The development of management organization structures is associated with difficulties. With consideration for the complexity of large enterprises, 
it is necessary to develop methods for determining the practicability and efficiency of changes in the management organization structure of the enterprise. Special attention should be given to the adaptability of the management organization structure to changing conditions in the process of the enterprise development.

In order to reliably estimate the compliance of the management organization structure of the enterprise with the requirements of the investor, it is necessary to use two estimation scales, that is, a semantic scale, with estimates ranged from a «bad estimator» to a «high estimate», and a numerical scale with estimates ranged from 0.75 to 1.05 .

The proposed management organization structure complies with the characteristic features of construction enterprises. The semantic an numerical estimation scales provide the possibility to determine the compliance of the management organization structure with the specified requirements and, as a result, to reduce expenses for reorganization of the enterprise, reduce the operational expenses of investors, and create conditions for activities of construction engineering companies in controlling investment resources in the process of preparing and implementing construction projects.

\section{CONCLUSIONS}

1. Management organization structure models are developed for construction enterprises with consideration for changes in the activities of the enterprise as a principal contractor ${ }^{10}$.

2. The management organization structure models are developed so as to effectuate all the advantages characteristic for the functional and administrative elements of management organization structures.

3. Special attention is given to the administrative elements of management organization structures, specifically to the department for risk management. The activities of the construction enterprise departments shall be oriented to perform such special functions as estimation of investment propositions, project objectives, design documentation, and sources of financial support, and to make decisions concerning relations of the enterprise as a principal contractor.

${ }^{10}$ Tugai O.A., Forming of the research and information basis for taking into account stochastic factors in construction organization and for preventing failures of organizational systems; Tugai O.A., Construction engineering, Kyiv, Kyiv National University of Civil of Engineering and Architecture, 2007, Issue 20, pp. 97-104. 
4. The proposed management organization structure complies with the characteristic features of construction enterprises. The semantic and numerical estimation scales provide the possibility to determine the compliance of the management organization structure with the specified requirements and, as a result, to reduce expenses for reorganization of the enterprise, reduce the operational expenses of investors, and create conditions for activities of construction engineering companies in controlling investment resources in the process of preparing and implementing construction projects.

\section{SUMMARY}

This paper concerns the development of new theoretical concepts and methods for the adaptation of management organization structures in construction to the current conditions. The novelty of the proposed methods consists in that these methods are developed on the engineering basis with consideration for changes in the operational and management activities of construction enterprises as principal contractors, implementation of new functional end engineering construction standards designed for verifying the quality of construction project decisions, and the capabilities of the project management personnel.

In order to improve the quality of construction and installation works and provide the compliance of construction objects with the specified requirements, it is necessary to develop new management organization models to be used in the process of interaction between the principal contractor and the customer. The interaction process is divided into 9 stages ranged from the stage of construction preparation to the stage of commissioning the construction object, and provides fob the assignment of a principal contractor with responsibility, according to the contract, for the following:

1. Proper use of the construction project resources.

2. Logistic and maintenance support of the construction project.

3. Timeliness of performing construction and installation works.

4. Compliance with the requirements of the appropriate standards.

In order to adapt the management organization methods to the current market requirements, the methods and models are developed with consideration for the new functions of construction engineering companies, risks in performing construction and installation works, necessity to 
introduce changes in the process of performing construction and installation works, and the requirements of new functional end engineering standards.

These methods and models provide the possibility to develop optimal management organization structures for construction engineering companies as principal contractors and to reduce expenses when performing analysis of the company activities at the preinvestment stage.

The results of research activities discussed in this paper provide the possibility to optimize management organization structures of construction enterprises. The proposed management organization structures comply with the process of intensive reorganization of the construction industry of Ukraine and provide favorable conditions for construction enterprises as principal contractors.

\section{REFERENCES}

1. Bovykin V.I., New management (management of enterprises in accordance with standards: theory and practice of effective management); Moscow, Ekonomika, 1997, 302 pp.

2. Bocharov V.Y., Investment management: management of investment activities; St. Petersburg, Publishing office of the Economy and Finance University, 1999, $284 \mathrm{pp}$.

3. Dmytruk I.A., Torkatiuk V.I., Mariukhin V.M., Characteristic features and basic areas of activities for enhancing efficiency of project decisions; Materials of the 23rd scientific and technical conference of the Kharkiv State Academy of Municipal Economy, Kharkiv, 2007, pp. 105-117.

4. Pokolenko V.O. and others, New methods of forming an investment portfolio in construction by optimizing the tax structure; Methods of increasing construction efficiency in market conditions, Collection of scientific papers, Kyiv, Kyiv National University of Civil Engineering and Architecture, 2006, Issue 15, pp. 3-10.

5. Pokolenko V.O. and others, New conceptual and analytical facilities for justification, preparation, and implementation of investment projects in construction; Monography under the editorship of Pokolenko V.O., Kyiv, Publishing office of the European University, 2008, 208 pp.

6. Tugai O.A., Lagutin G.V., New subjects of construction organization: methods, information base, and implementation practice; Monography, Publishing office of the European University, 2006, $180 \mathrm{pp}$.

7. Tugai O.A., Multi-stage engineering model for organization of interaction between the principal contractor and the customer; Tugai O.A., 
Construction engineering, Kyiv, Kyiv National University of Civil Engineering and Architecture, 2008, No. 21, pp. 85-97.

8. Tugai O.A., The functional-technical factor of efficiency of projects and structures of construction engineering companies as a new parameter in simulation of construction; Tugai O.A., Applied geometry and engineering graphics, Interdepartmental collection of scientific papers, Kyiv, Kyiv National University of Civil Engineering and Architecture, 2008, Issue 79, pp. 140-150.

9. Tugai O.A., Method of functional-technical reorganization of construction; Tugai O.A., Town development and territorial planning, Collection of scientific papers, Kyiv, Kyiv National University of Civil Engineering and Architecture, 2006, Issue 30, pp. 398-419.

10. Tugai O.A., Forming of the research and information basis for taking into account stochastic factors in construction organization and for preventing failures of organizational systems; Tugai O.A., Construction engineering, Kyiv, Kyiv National University of Civil of Engineering and Architecture, 2007, Issue 20, pp. 97-104.

\section{Information about the author:}

Tugai O. A.,

Doctor of Engineering Science, Professor, Head of the Construction Organization and Management Department, Kyiv National University of Civil Engineering and Architecture 31, Povitroflotskyi ave., Kyiv, 03037, Ukraine 